\title{
榴熱病 の生化學的研觉
}

（第 4 報）稻熱病菌の榮䓹吸收に及ぼすアンモニヤ態及び硝酸熊塋素の影響

田中正三・香月裕彥・香月文子

TANAKA, S., Katsuki, H. \& KaTSUKI, F.: Biochemical studies on the blast disease of rice plant. IV. Effect of different nitrogen sources in the culture media upon the nutritional absorption of the blast disease fungus.

\section{1. 緒 言}

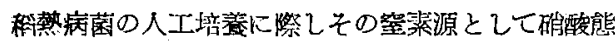

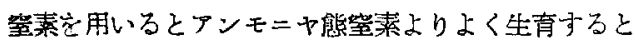
報告されてをりり，我及の敉富に於いても硫酸アンも

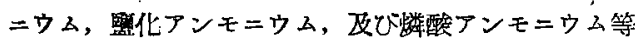

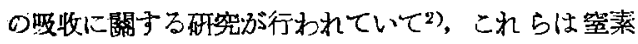
源として不適當であることが認められている。程熱病 菌は婠基基性で酸性に弱く，酸性の限界として三宅， 足立雨氏(3) $\mathrm{pH} 3.7$, 西門氏は3) $\mathrm{pH} 5.0$ 附近と報じ ている。從つて培地の絰槂源として使用したアンモ二

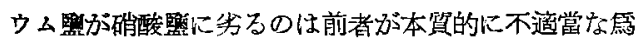
ではなく、アンモニウムイオンの撰擇吸收に上る培地 の $\mathrm{pH}$ の低下の結果であるとの推定が行われる。又

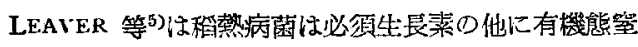
素定必要とすると報告してをり，ここに別な空素源の 問題が提出され，著者等はこの間題它解明する临，一

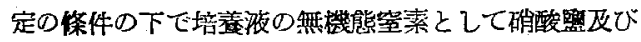

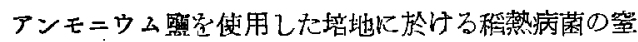

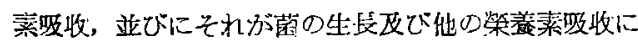

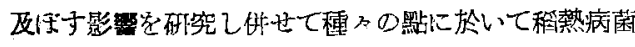

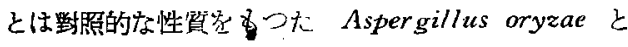
○此較苋行つた。

\section{2. 賽驗 部}

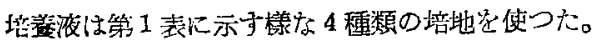
これらの4種の培地の窒素源のモル数及び䇪䋕，䊁酸， カリウムの夫ネの量を培地 $\mathrm{A}$ 染基隻にした比で表わ せば第 2 表となる。そ,他の䇫驗操作は第一報) と同

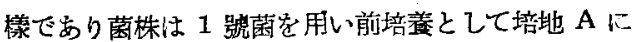

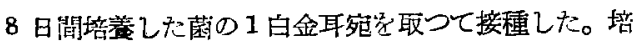
䈍溫度は $28^{\circ} \mathrm{C}$ である。一定日數每に培荃フラスコの

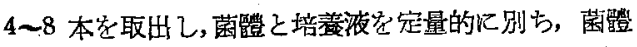

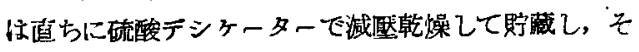
の1部につき水分を定量し全生舆量を計出した。培等 液は值ちに $\mathrm{pH}$ 艺測定した啳, 還元糖, 非還元糖は第

* 京都大學理學部化學教室
第 1 表

\begin{tabular}{|c|c|c|c|c|}
\hline 塔。 & & & C & D \\
\hline 一燐酸 力 & & 0.25 & $.25^{\circ}$ & .96 \\
\hline 燐 酸 力 & & & & \\
\hline 酸＼cjkstart苦 & & $0, \angle 0$ & & \\
\hline 石 & & 0.05 & 0.05 & 0.05 \\
\hline 酸 & & & - & \\
\hline 肖酸 $ア ン モ ン$ & & 0.792 & 0.396 & \\
\hline 笊二燐酸アンモン & - & - & 一 & 0.65 \\
\hline 化 第 二 鐵 & 恨跡量 & 浪跡点 & 痕跡量 & 痕跡: \\
\hline 酸＼cjkstart石 & & 一 & - & 1.70 \\
\hline & & & & 15.00 \\
\hline 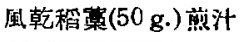 & & & & $1 \mathrm{~L}$ \\
\hline
\end{tabular}

第 2 表

\begin{tabular}{|c|c|c|c|c|c|c|}
\hline & & 地 & A & $B$ & C & D \\
\hline \multicolumn{3}{|c|}{ 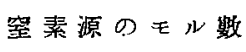 } & 1 & 1 & 1 & $\frac{1}{2}$ \\
\hline 窑垔 & 素 & 量 & 1 & 2 & 1 & 1 \\
\hline 力 & y & 量 & 1 & 1 & 1 & 0.562 \\
\hline 燐 & 酸 & 量 & 1 & 1 & 1 & 3.84 \\
\hline 其 & の & 他 & & & & $\mathrm{CaCO}_{3}$ \\
\hline $\mathrm{pH}$ & & & 5.5 & 5.5 & 5.5 & 5.7 \\
\hline
\end{tabular}

1 報にのベた方浩で，アンモニヤは水酸化カルシウム

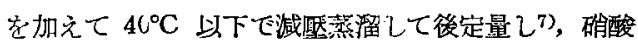
根は葓性ソーダで强アルカリ性にして DEVAKDA 合

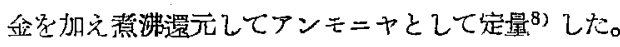

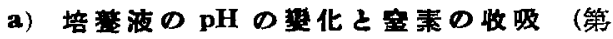

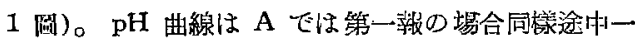
時的な下降を示字他怯上昇の一途定たどつている分， Bては初为激しく下降し 3.8 亿達し乞れ上後は急激に 高くなつている。Cては初期の下降現像が僅か心認め られた後 B の埸合と同じ型の上鼠宗している。D では殆ど㐿化がない。

この榜な $\mathrm{pH}$ 曲線に現われた綎化は含筀イオンの 曼收の綜渠によることは明らかで A では專ら磪酸根

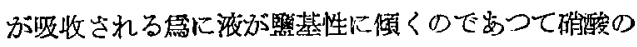



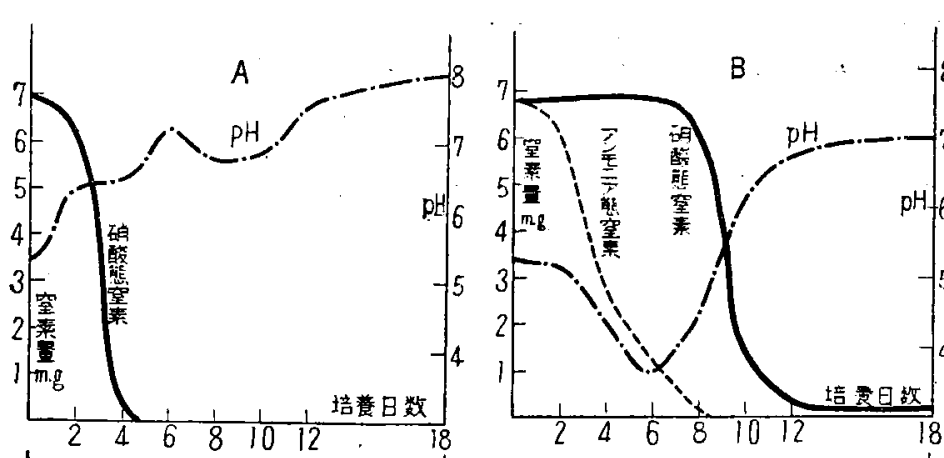

b)回の生最已被の樶
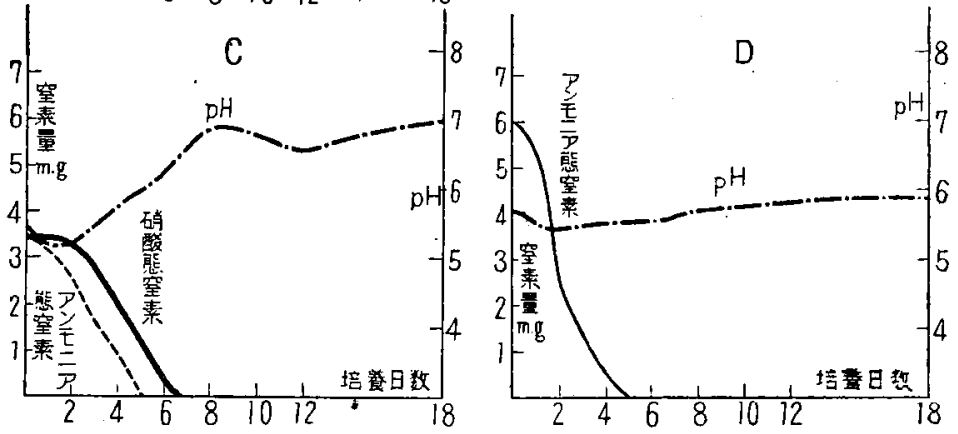

收（第 2 圆）第 2 圆に示卞 如く菌の生長は2日目にはD が最も早くAはこれに次いて 6 いるが，その㷋の生長速度は Aが最速くなつている。B, C 共焙地の $\mathrm{pH}$ が下降して いる間は生長は弉く，特飞 B では氣中菌絲は全く生成せず 㳔中菌絲を異常な外頼老呈し た。乙の場合液の $\mathrm{pH}$ は蘶の 生育可能の酸性限界に近いる H7のと推定することができる。 糖の吸收は活活生長々本行 乙，生長逨度が大だある場合 には糖の罗收速度も大で り, 叉何れの場合生長最大

4 を示声時期には精は完全吸玫 されてをりこの條件では糖 量が生長の時期的な制限因子

第 1 圆 となつている。

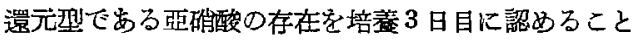

3. 考 察

ができたがその後は亞硙酸並びにアンモニヤ它全く檢

以上の結果から明かなように稻熱病菌には壆莱源と

出できなかた。Bでは

最初はアンモニウムイォ 800 ンの撰擇吸收が專ら行わ れ，硝酸根は殆ど吸收さ れていない。この扁 $\mathrm{pH} 500$ は極度に酸性になるが， 6 日目にアンモニャが吸 30 收され盡す須になると砽 200 酸根の罗收方㕸ま口, $\mathrm{pH} 100$ 曲線は逆轉して上昇学始 めるのである。Cでも同 800 上

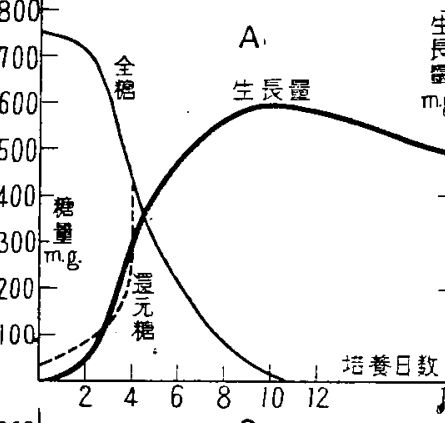
m.g-300 600- 全 全 B

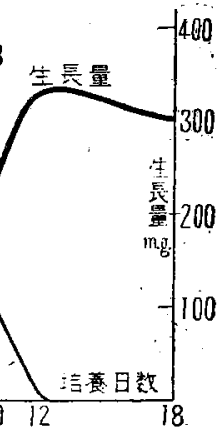

こ傾向が認められるが, 确酸アンモニウムの濃度 が低い煘，この傾向はそ れ程明瞭でない。Dでは アンモニウムイオンは急 激に吸收されているが， 炭酸カルシウムが存在す る骨に中和されて培被液 の pH の㩆動は殆ど起ら ないのである。
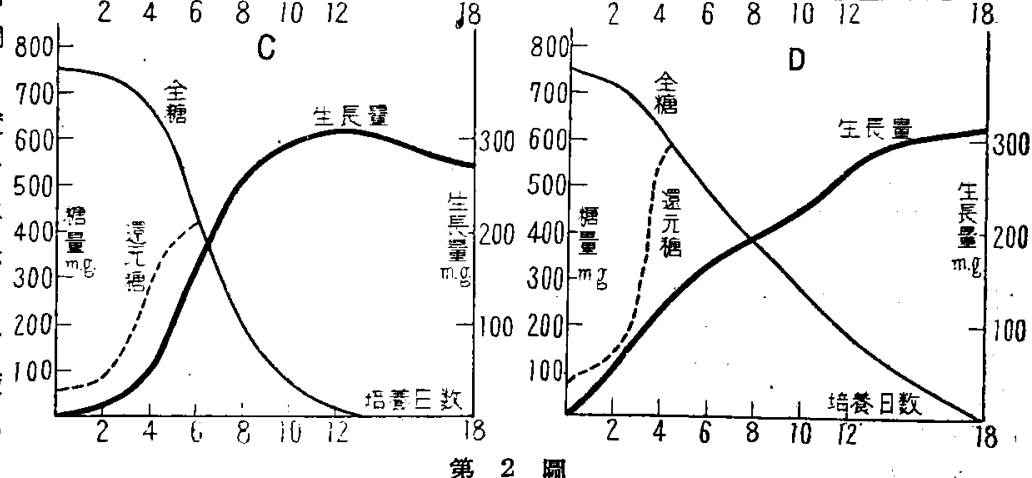

第 2 圆 
して與穴たアンモニヤは㴽して不通當なるのでなく， 選摆㙏收による培地の酸性化の影繁が生育不良を招來 する原因となるすの で, アンモニヤ態跑素 は本菌の良好な荎索源 であることが明らかと なつた。又 $\mathrm{A}$ に於て 确酸摆元成嗉遭である 亞确酸, アンモニヤが 培盖液中に硝えど現わ れて來ないので B, C, に於ける确酸及びアン

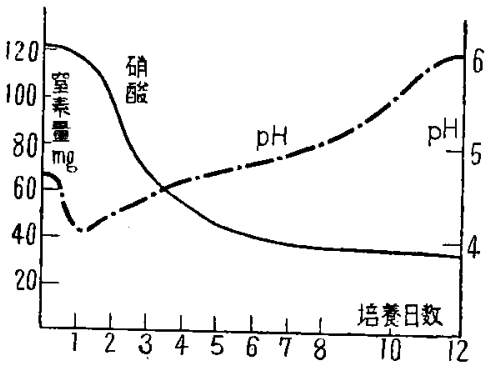

モニヤの定量數值はそのまま各々の選擇吸收の狀態を

現わしていると考えて長いと思われるから B の場合 に明らか認められる如く先ずフンモニヤが僈先的に 四收され後に硝酸の吸收汸行われるすのと推定するこ そができるこの現象は硝酸フンモニウムの浱度が大だ ある程著しい。

この結果を稻熱病菌とは棰々の照で對照的な $A s p$ ergillus oryzae について同樣な算驗学行つた結果を 示すと第 3 圆及び第 4 圆の上万になる。郎ち培堎液 は硝酸カリウム: $18 \mathrm{~g}$, 第一憐酸カリウム: $5 \mathrm{~g}$, 硫酸 マグネシウム $: 2.5 \mathrm{~g}$, 㯺化カルシウム $: 1 \mathrm{~g}$, 暨化第

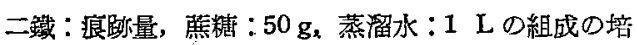
地に於いて $33^{\circ} \mathrm{C}$ て培䓪した場合には第 3 圆に示すよ 万生育に件つて少量の亞硝酸及び多量のアンモニヤ の蓄積が見られるよらになる。
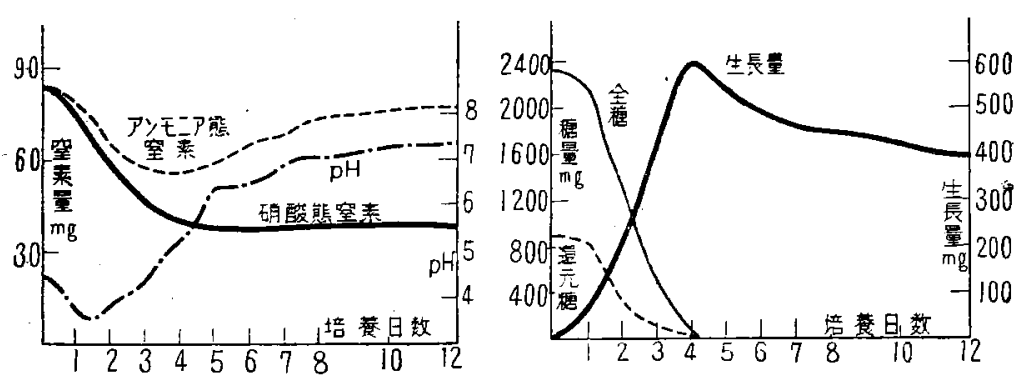

第 4 阙

この培羙液の硝酸カリウム定硝酸アンモニウム：

$10 \mathrm{~g}$ に置き換えると生長は遥加早くなるが, この場 合は碓酸の澴元型であるアンモニアの多量が蓄䖽され 培地の $\mathrm{pH}$ は極度に偏ることなく, 最初から硝酸及び アシモニアの雨方名吸收している事が制る。(第4 圆)

この2種の絲狀菌の比輘から比輘的酸性に强い Aspergillus oryzae だはアンモニウムイオンと碓酸イオ

第 3 圖 了解することができよう。 て表示すると第 3 表のよらになる。

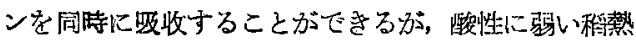

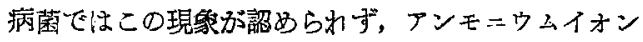

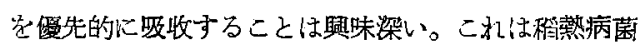

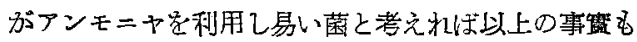

次に菌の生育中に於ける生理的活性度志比较方る日

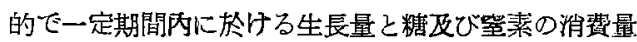
恣夫 $\Delta \mathrm{G}, \Delta \mathrm{S}, \Delta \mathrm{N}$ と乙，それらの相互の比を求ぬ

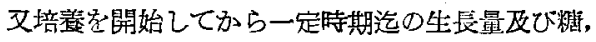
跮素の吸收量を夫ょ $\mathrm{G}, \mathrm{S}, \mathrm{N}$, としそれらの相五の比 を求めると第 4 表のよらな結果となる。

※ 但乙下線定引いた數值は生長最大期のものを示 方。括弧をつけた数值は自己消化期のるの宗す。

第 3 表に於て $\Delta \mathrm{N} / \Delta \mathrm{G}$ は生長初期に於いて A では B, C, D の場合より低い值家示し，文第 4 表の N/S に

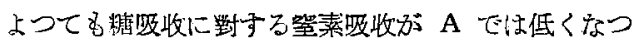
ていることで明らかで ある。

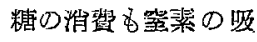
收同化，培地の $\mathrm{pH} の$ 孌化の影慗を受けてを り, 生長の制限因子は 桷に，生長速度は䇪菜 同化及びこれに件う培 地の pH の戀化に制限 されているよらである。

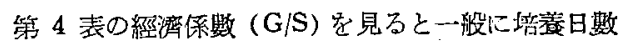
が淮むにつれ值が低くなつているが，これは若い菌は エネルギーの大部分を菌鿷楧成に使万に對し，古い菌 では生命維持のエネルギー定必要とするための差で ろら。培善初期にこの值は A では他に比へてかなり 低い值悐示しているのは硝酸をアンモニヤに還元する に糖艺使用する胥と解される。又 Bに於いてこの值が 


\begin{tabular}{|c|c|c|c|c|}
\hline 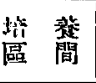 & 䏴 地 & $\frac{\Delta G}{\Delta S} \times 100$ & $\frac{\Delta N}{\Delta G} \times 100$ & $\frac{\Delta N}{\Delta S} \times 100$ \\
\hline \multirow{4}{*}{$2 \stackrel{0}{\mid}$} & A & - & 3.8 & 4.0 \\
\hline & B & - & 7.36 & - \\
\hline & $\mathrm{C}$ & - & 6.70 & -- \\
\hline & $\mathbf{D}$ & - & 5.90 & 12.0 \\
\hline \multirow[b]{2}{*}{2 日 } & A & 45.0 & 4.05 & 1.82 \\
\hline & B & 47.8 & 8.78 & 4.10 \\
\hline \multirow[t]{2}{*}{4 日 } & C & 42.2 & 8.20 & 3.56 \\
\hline & $\mathrm{D}$ & 49.0 & 3.69 & 1.78 \\
\hline \multirow[b]{2}{*}{4 日 } & $A$ & 36.8 & 0.55 & 0.20 \\
\hline & $\mathrm{B}$ & 48.1 & 5.70 & 2.65 \\
\hline \multirow[t]{2}{*}{6 日 } & C & 49.4 & 2.13 & 1.05 \\
\hline & $\mathrm{D}$ & 38.6 & 0.72 & 0.28 \\
\hline \multirow[b]{2}{*}{6 日 } & A & 34.2 & 0 & 0 \\
\hline & B & 29.3 & 5.86 & 1.72 \\
\hline \multirow[t]{3}{*}{8 日 } & C & 38.2 & 0.250 & 0.078 \\
\hline & $\mathrm{D}$ & 26.1 & 0 & 0 \\
\hline & A & 29.6 & 0 & 0 \\
\hline 8 日 & B & 44.3 & 3.73 & 1.62 \\
\hline \multirow{2}{*}{ 11日 } & C & 34.4 & 0 & 0 \\
\hline & D & 39.4 & 0 & 0 \\
\hline & A & $\overline{ }$ & $\longrightarrow$ & $\longrightarrow$ \\
\hline 10日 & B & 45.6 & 1.24 & 0.56 \\
\hline \multirow[t]{2}{*}{ 12百 } & C & 30.3 & 0 & 0 \\
\hline & $\mathrm{D}$ & 41.8 & 0 & 0 \\
\hline
\end{tabular}

䅌々高いのは他に比へて学素源が多い篇でらる。この 事富は第 3 表のN/S が A，C，Dでは約 1 であるか， Bでは 1.81 を示すことによつてる时らかである。

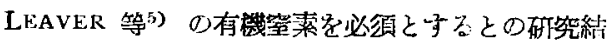

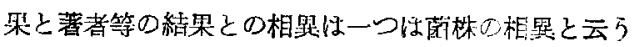

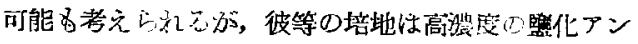
モニウム，硫酸アンモニウムを使用しているので著者

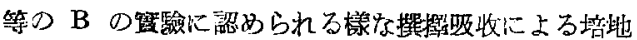

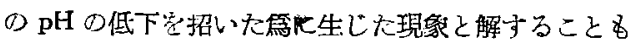

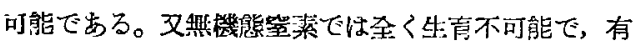

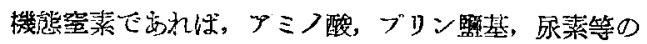
いかなる形とも空素源として良く利用品れると云万彼

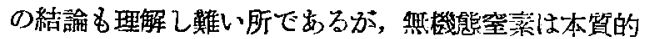

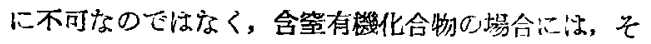
の絠徨作用のため堷地の酸性化虎防止した結果となつ たと考えることあ出來る。

\section{4. 摘 要}

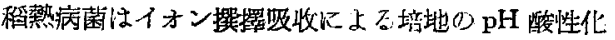

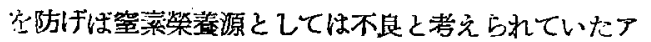
ンモニヤ学是く利用同化するととが歫明した。及窒素 源として磪酸アンモニウムの形ともたえると、アンモ

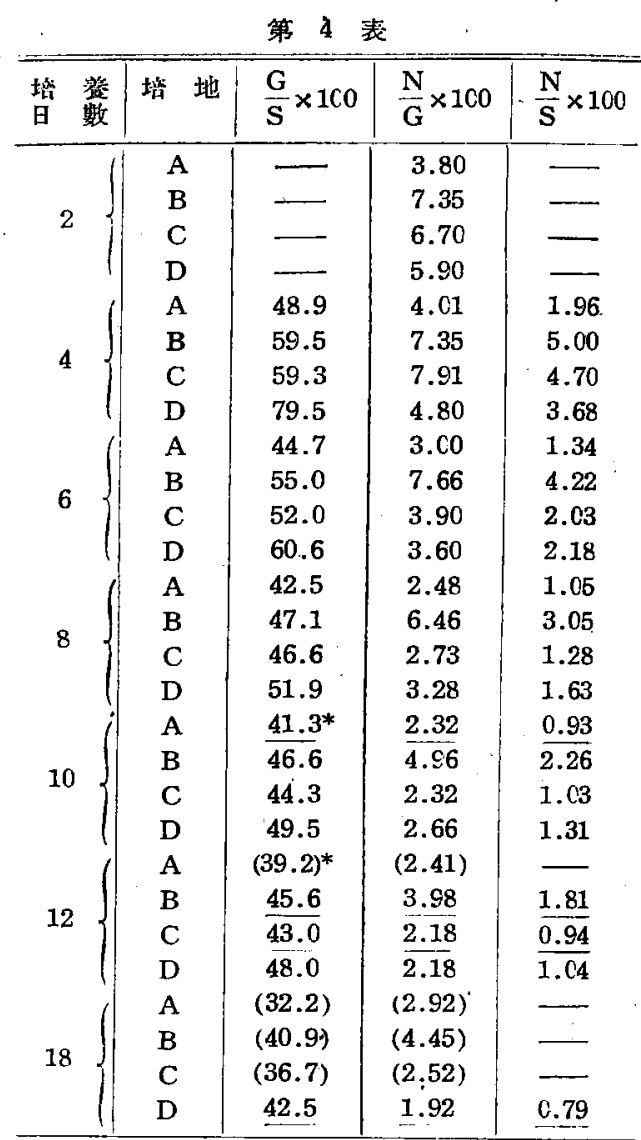

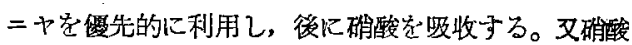

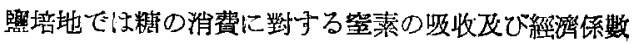
がアンモニウム培地に比して低いが，乙れは硝酸の還

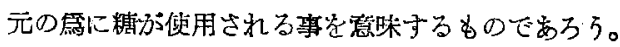

\section{文献}

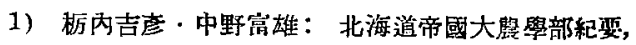
$41: 183(1940)$

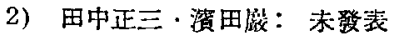

3) 三宅康次·足立仁：Jour. Biochem., $1: 223$ (19 23)

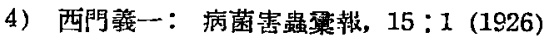

.5) Leaver F. W., JEAi. J. \& Brewer C.R.: Jour. Bact., $54: 401$ (1947)

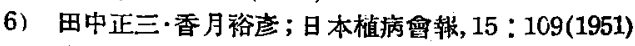

7）赤㻕四部：アミノ酸及び蛋白質：p.188昭 19 共 立辣:

8) Treadwell F.P.: Analytical Chemistry Vol. 2 p. 454 (5th ed.)

9) 田中正三・香月裕吝：昭和 26 年 5 月植物病理 學會軿演發表 